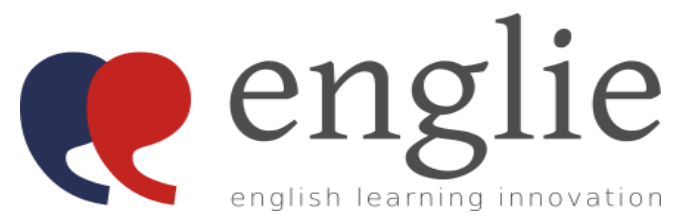

\title{
Pre-Service English Teachers' Pedagogical Competence in Teaching English: A Case of Teaching Internship Program (TIP)
}

\author{
${ }^{1}$ M. Ali Ghufron, ${ }^{2}$ Ahmad Taufiq, ${ }^{3}$ Muhammad Riskiyanto \\ ${ }^{1,2}$ Post-Graduate Program, IAIN Pekalongan, Central Java, Indonesia \\ ${ }^{3}$ IKIP PGRI Bojonegoro, East Java, Indonesia \\ Corresponding Author: m.ali.ghufron@iainpekalongan.ac.id
}

\begin{abstract}
Pre-service English teachers (here: PETs) play a critical role in the development of students' academic knowledge, technical skills, social values, and individual personalities, as well as their ability to digest teaching materials properly. Considering what is known as the pedagogical competence of pre-service English teachers is an important part of this process. This study aimed at evaluating the pre-service English teachers' pedagogical competence in the classroom while instructing pupils in the English language. This study employed a qualitative research approach, especially a case study method with five Indonesian pre-service English teachers who participated in a teaching internship program (TIP) to collect information. The researchers used a range of approaches to acquire information from the perspectives of the student-teachers. These methods included questionnaires, observations, and observation notes. During the data analysis phase, the researchers used data reduction, data visualization, conclusion writing, and verification to help them make sense of their findings. In addition, the triangulation procedure was used to examine and validate the information gathered from the participants throughout the research phase of the investigation. According to the results of this research, pre-service English teachers' pedagogical competence was good, with an average score of 3.33 out of 5 on the pedagogical competence score (67 percent). Pre-service English teachers will benefit from reflection-based instruction and extended teaching practice under the supervision of experienced instructors in English Language Teaching (ELT) practices.
\end{abstract}

Keywords: Case study, pedagogical competence, pre-service English teachers (PETs), studentteacher, teaching internship program (TIP)

ABSTRAK
Mahasiswa calon guru Bahasa Inggris memiliki peran yang penting dalam membantu
perkembangan pengetahuan akademis siswa, keterampilan teknis, nilai-nilai sosial, kepribadian
siswa, dan juga kemampuan dalam memahami materi pembelajaran dengan baik. Oleh karena itu,
keterampilan pedagogis bagi mahasiswa calon guru Bahasa Inggris adalah suatu bagian penting
dalam proses tersebut. Penelitian ini bertujuan untuk mengevaluasi keterampilan pedagogis
mahasiswa calon guru Bahasa Inggris dalam pengelolaan pemebelajaran Bahasa Inggris di kelas.
Penelitian ini menggunakan sebuah pendekatan penelitian kualitatif, yaitu metode studi kasus
dengan melibatkan 5 mahasiswa calon guru Bahasa Inggris yang telah melaksanakan kegiatan


PPL (Program Pengalaman Lapangan). Tim peneliti menggunakan berbagai pendekatan dalam menggali data/informasi dari responden. Beberapa cara penggalian data yang digunakan diantaranya adalah pemberian angket (survei), observasi, dan catatan lapangan. Data/informasi yang diperoleh selajutnya dianalisis dengan cara reduksi data, penyajian data, pengambilan simpulan, dan verifikasi apakah data/informasi yang diperoleh sesuai dengan rumusan masalah dan temuan penelitian. Selain itu, tim peneliti juga menggunakan prosedur kroscek data (triangulasi) untuk menguji keabsahan data/informasi yang telah diperoleh dari partisipan. Hasil penelitian ini menunjukkan bahwa mahasiswa calon guru Bahasa Inggris memiliki keterampilan pedagogis yang 'Baik', dengan rata-rata skor 3.33, dari rentangan nilai 1 s.d. 5, atau setara dengan nilai $67 \%$. Penelitian dan program PPL ini memberikan manfaat yang signifikan bagi mahasiswa calon guru karena mereka akan memperoleh pengalaman pembelajaran yang berbasis refleksi dan juga mendapatkan bimbingan dari guru pamong yang telah berpengalaman dalam praktik pembelajaran Bahasa Inggris.

Kata Kunci: Keterampilan pedagogis, mahasiswa calon guru, mahasiswa calon guru Bahasa Inggris, program pengalaman lapangan (PPL), studi kasus

\begin{tabular}{|l|l|l|}
\hline $\begin{array}{l}\text { Received: } 26 \text { December, } \\
2021\end{array}$ & $\begin{array}{l}\text { Accepted: 16 February, } \\
2022\end{array}$ & $\begin{array}{l}\text { Published: } 17 \text { February, } \\
2022\end{array}$ \\
\hline
\end{tabular}

How to cite:

Ghufron, M.A., Taufiq, A., \& Riskiyanto, M. (2022). Pre-service English teachers' pedagogical competence in teaching English: A case of teaching internship program (TIP). English Learning Innovation, 3(1), 27-41.

https://doi.org/10.22219/englie.v3i1.19382

\section{INTRODUCTION}

Teachers play a crucial role in ensuring that students accomplish their educational goals and aspirations. In addition, they are the most important persons in the entire classroom setting, as they are in charge of managing learning experiences and learning settings. In order to help students learn, teachers use themselves as well as their knowledge, talents, attitude, and practice to assist students in their learning. The success of students' learning is heavily dependent on the teachers' willingness to initiate the activity (Namunga \& Otunga, 2012). When it comes to improving students' achievement, teachers have a significant impact, and their impacts on student learning tend to be longlasting and cumulative (Darling-Hammond et al., 2009).

According to a number of literatures, good competences and performance are required from teachers and participation in professional development, engagement with contemporary concerns, and ethical task performance in the classroom. Workshops, mentorship, and training are examples of professional development opportunities that teachers must take advantage of to be effective in their positions (Tanang \& Abu, 2014). It is a priority for education systems and teachers to invest in professional development 
since teachers need to keep their skills and knowledge up to date. Teachers' knowledge and pedagogical abilities are developed through professional development programs, enhancing their confidence in the classroom and helping them create a positive attitude toward teaching and student learning (Radford, 1998; Stein et al., 1999).

As part of their teacher education programs, Pre-service English teachers are assigned to undergo a teaching internship program (TIP) that entails direct contact with students in addition to their student teaching. A TIP program allows pre-students to gain practical experience in the teaching process with guided and supervised instruction. TIP is an essential program in each teacher education program because it provides an opportunity for Pre-service English teachers to put their newly acquired knowledge into action in a real classroom setting (Doering \& Beach, 2002; Ulla, 2016). In TIP, a mentor or cooperating teacher eases the college student into the instructor position for a certain class over many weeks. As the experience develops, the cooperating teacher collaborates with and encourages the Pre-service English teachers to accept increasing responsibility in classroom management and instructional delivery. The Pre-service teacher begins as an observer and becomes a competent professional after the Pre-service teaching experience. Teacher education focuses on helping future educators study, learn about teaching and apply what they have learned to serve their pupils (Avalos, 2011). Therefore, TIP's ultimate objective is to demonstrate proficiency in fundamental abilities necessary to enter the teaching profession (Adnyani, 2015; Ulla, 2016).

Several studies have been conducted on pre-service English teachers and their teaching practicum experiences (Cho et al., 2020; DeLuca et al., 2013; Downing \& Dyment, 2013; Lohbeck et al., 2018; Salajan et al., 2016; Siwatu, 2011; Ulla, 2016). Cho et al. (2020) looked at the variables that impact pre-service English teachers' beliefs about their abilities to fulfil the cultural and linguistic needs of diverse learners. It was found that pre-service English teachers had low self-efficacy in interacting with English language learners (ELs), while having high self-efficacy in a range of learning modalities, according to the findings of the data analysis. Meanwhile, through the practicum experiences of 21 junior and senior BSEd and BA English student-teachers from a private institution in Mindanao, Philippines, who were put in a Pre-service teacher training program, Ulla (2016) performed research on the Philippines' pre-service teacher training programs. Pre-service teacher preparation programs in both BSEd and BA English were 
found to have a separate approach towards standardization. While the BSEd-English program was designed to produce high school professional teachers, the BA-English program was designed to produce teachers and professionals with exceptional communication talents. In another study, using the wiki platform, Salajan et al. (2016) studied whether pre-service teachers' lesson planning abilities might be improved in a Midwestern university teacher education program in the United States. The results show that teacher candidates' lesson planning abilities increased as a result of integrating comments obtained via peer review in a wiki setting. In addition, Lohbeck et al. (2018) through their research reveal that educational skills, subject material knowledge, consultation, invention, media use and diagnostics, as well as the three emotions (pleasure, anger, and anxiety) were conceptually separated, as were the relationships between these categories. After that, their research revealed that all components of one's personality, including emotions, can be clearly distinguished.

From the previous studies above, it is concluded that pedagogical competence as one of the factors that influence teaching skills is still needed to be investigated. A substantial effect on the outcome of teaching and learning is pedagogical competence, which is one of the most important of all teaching skills. Pedagogical competence is concerned with the abilities that are required for the management of classroom practice. Moreover, it requires teachers to have a grasp of their students' needs, to be knowledgeable about instructional theories and ideas as well as about curriculum, learning evaluation, and self-reflection about their classroom practices. Because of this, instructors are expected to be well-versed in the process of learning as well as putting their newfound knowledge into practice in the classroom setting (Eggen \& Kauchak, 2001). Further, Ryegård et al. (2010) state that pedagogical competence demonstrates the teacher's skills in cooperating with colleagues, having a holistic approach, and making a substantial contribution to the development of pedagogy at postsecondary institutions. Going from this consideration, the researchers conducted this study focusing on evaluating Pre-service English teachers' pedagogical skills in teaching English during teaching internship program (TIP). 


\section{METHOD}

\section{Research Design}

In this study, the researchers conducted a qualitative case study research design. In qualitative research, the focus is on individuals investigated, investigating phenomena from their viewpoints while considering the social context. Research that incorporates interpretative the naturalistic methodology is also included (Denzin \& Lincoln, 2005; Kihlgren, 2016). It may also be utilized to answer several kinds of research questions: explanatory, descriptive, and exploratory (Johnson \& Christensen, 2019; Stake, 1995) in its real-life situation (Yin, 2003). Thus, it makes sense to adopt a case study method in this study since the focus is on individuals and phenomena from their perspective while taking into account the social environment.

\section{Participants and Context}

The participant in this study was chosen by a process known as purposive sampling (Bloor \& Wood, 2016; Creswell, 2012; Oliver \& Jupp, 2006). Purposeful sampling refers to the process by which researchers purposefully pick persons and places in order to learn about or better understand the basic phenomena under investigation (Creswell, 2012). The criteria for choosing participants and locations are such as being "information-rich," "engaged in the case," and even "excited to participate in the research,"(Creswell, 2012; Patton, 2002). From those criteria, therefore, this study involved five English teacher candidates (i.e., from undergraduate program) who had engaged in a teacher education program, specifically the TIP.

The participants were drawn from a private institution in East Java province, Indonesia. They were Pre-service English teachers who had previously completed mandatory courses related to teaching and learning, including TEFL, EFL Curriculum and Materials Development, Teaching and Learning Media, Language Teaching Evaluation and Assessment, and Instructional Design. After that, the participants conducted teaching and learning practice in TIP within a two-month time frame in a State Islamic Senior High Schools (Madrasah Aliyah Negeri). During the program, they were supervised by senior English language teachers. They were guided from the planning, implementation, and evaluation phase. 


\section{Data Collection and Instruments}

Several ways of data collection were used to gather information, including surveys (questionnaires), observations, and observation notes based on the student teacher's perspective. The non-participant observation was used to collect data during the Teaching Internship Program. It involves studying people and locations at a research site (using predetermined criteria) (Creswell, 2012). Direct or indirect observation allows researchers to see what individuals are doing or saying. Also, during an observation, the researchers gathered observation notes. To assess participants' pedagogical competence, the observation checklist (adopted from Indonesian Ministry of National Education) utilized a Likert scale from 1 (poor) to 5 (excellent).

The survey questionnaire, an open-ended questionnaire, was administered to elicit detailed information on participants' perceptions of their teaching-learning activities. They were asked to provide feedback on their teaching abilities and practices throughout TIP. While the subjects completed the questionnaire, the researchers validated the observation results based on questionnaire results. It is reasonable to expect that the questionnaire answers will be examined and analyzed in light of the observation results and observation notes, thereby ensuring that the information obtained is verifiable and accurate. (Note: the results of observation and observation notes are presented in another part of this study).

\section{Data Analysis}

As mentioned previously, this study aimed to evaluate the degree to which the pedagogical competence of the Pre-service English teachers during TIP in the teaching of the English language. Therefore, the researchers used observation, observation notes, and questionnaires to elicit the data dealing with the research objectives. The data yielded from those techniques were in the form of qualitative data. Therefore, to analyze qualitative data, the researchers followed Creswell's (2012) principles, i.e., data preparation and organization, data exploration and database coding, data description and topic formation, data representation and reporting, data interpretation, and validation.

\section{Procedure}

The researchers created the indicators used to measure participants' pedagogical competence garnered from the related theories for investigation purposes. The indicators 
used are understanding students' characteristics, mastering teaching and learning theories and their principles, developing curriculum (e.g., syllabus and lesson plan), performing educational activities, developing learners' potentials, fostering communication and engagement with pupils, and conducting assessment and evaluation. After that, the research team developed the instruments, such as observation checklist, observation notes, and open-ended questionnaires that would be used to gather the data by referring to the indicators. The instruments were also validated their content and construct. After the instruments were validated, the researchers employed the participants to elicit the data.

\section{FINDINGS AND DISCUSSION}

\section{Pre-service English Teachers' (PETs) Pedagogical Competence in TIP}

Sustainably, all PETs have previously undergone pedagogical growth during their university teacher education. If it has this effect, they could view English language teaching and learning in a new light and use their newly-acquired insights to design more successful and efficient teaching-learning activities. PETs in the Teaching Internship Program (TIP) will use teaching-learning theories that they acquired in class and apply them to the classroom, including emotional involvement, enthusiasm, expectation, and beliefs. Because of this, this study revealed that PETs used English teaching approaches based on their ideas.

A two-week observation revealed that PETs in TIP possess a considerable pedagogical ability. Their pedagogical competence scores were found to be 3.33 on average. It indicates that they had performed well during their first time teaching English. So, the observations yielded the data found in Table 1, which includes all the pedagogical aspects scores.

Table 1. PETs' Pedagogical Competence during TIP

\begin{tabular}{cccccccccc}
\hline & \multirow{2}{*}{ No. } & \multicolumn{9}{c}{ Indicators of PC } & \multicolumn{2}{c}{ Average } \\
\cline { 3 - 8 } & & $\mathbf{a}$ & $\mathbf{b}$ & $\mathbf{c}$ & $\mathbf{d}$ & $\mathbf{e}$ & $\mathbf{f}$ & $\mathbf{g}$ & Score \\
\hline 1 & Respondent 1 & 3.17 & 3.17 & 3.63 & 3.00 & 3.07 & 3.42 & 3.30 & 3.25 \\
\hline 2 & Respondent 2 & 3.67 & 3.67 & 3.63 & 3.64 & 3.50 & 3.67 & 3.10 & 3.55 \\
\hline 3 & Respondent 3 & 3.50 & 2.92 & 3.75 & 2,86 & 3.00 & 3.17 & 3.10 & 3.18 \\
\hline 4 & Respondent 4 & 3.17 & 3.17 & 3.50 & 3.09 & 3.07 & 3.42 & 3.60 & 3.29 \\
\hline 5 & Respondent 5 & 3.08 & 3.33 & 3.63 & 3.23 & 3.50 & 3.75 & 3.20 & 3.39 \\
\hline & Average & 3.32 & 3.25 & 3.63 & 3.16 & 3.23 & 3.48 & 3.26 & $\mathbf{3 . 3 3}$ \\
\hline
\end{tabular}


M.Ali Ghufron, Ahmad Taufiq, Muhammad Riskiyanto
Pre-Service English Teachers' Pedagogical Competence in Teaching English: A Case of Teaching Internship Program (TIP)
Notes:
$\mathrm{a}=$ understanding the characteristics of students
$\mathrm{b}=$ mastering teaching \& learning theories and their principles
$\mathrm{c}=$ being able to develop curriculum
$\mathrm{d}=$ being able to conduct educative learning
$\mathrm{e}=$ being able to develop learners' potentials
$\mathrm{f}=$ being able to maintain communication and interaction
$\mathrm{g}=$ being able to conduct assessment and evaluation

\section{The ability to understand the characteristics of students}

There are several ways to look at the characteristics of a student, such as physically, intellectually, socio-emotionally, morally, and spiritually (Alghasab, 2015; Köksal \& Çöğmen, 2013; Uka, 2013). When it came to understanding student characteristics, the observational checklist found that PETs, on average, had a score of 3.32. Students' learning styles were identified by PETs (on average 3.2), and equal class participation was ensured and distributed (average 4.0). The classroom was managed to deal with students' diverse competences (average 3.3), and problems and concerns about students' performance were resolved (average 3.0). It was crucial for PETs to understand their pupils on the intellectual, socio-emotional, and moral levels.

\section{The ability to master teaching and learning theories and their principles}

Unquestionably, PETs have studied the theory of learning (Redmond \& Lock, 2019) during their study, which includes learning approaches, methods, and techniques, classroom organization, the concept of classroom instruction, lesson plans, learning media, and the use of ICT. PETs' preparation program must focus on lifelong, meaningful, and enjoyable learning activities (Köksal \& Çöğmen, 2013). As a result of this orientation, they are more likely to carry out their responsibilities in the classroom.

Results show that PETs' ideas on teaching and learning English have the biggest influence on teaching. Regarding understanding teaching and learning theory and ideas, PETs had an average score of 3.25. To demonstrate this, they were tested on their ability to: manage various teaching methods in the classroom (on average 3.2); ensure students' comprehension; explain the important reasons to learn such materials in relation to reallife (average 3.0); apply strategies to engage students in the learning activity (average $3.0)$. 


\section{The ability to develop a curriculum (e.g., syllabus and lesson plan)}

Language curriculum development encompasses various educational activities, including curriculum creation and research. In developing a curriculum, the major goal is to identify what children learn in school, what learning opportunities should be offered to achieve the desired learning objectives, and how to plan, assess, and evaluate classroom practices (Richards, 2001).

According to the data, PETs prepare lesson plans based on the 2013 National Curriculum. Dealing with the competence of lesson planning activity, they had an average competence of 3.63. The majority of the PETs must focus on curriculum or lesson plan development, such as designing the syllabus (average 4.0), designing the lesson plan (average 4.0), and implementing the steps of teaching-learning in accordance with learning objectives (average 3.5). They must also select learning materials that are appropriate for their students (average 3.0).

\section{The ability to conduct educative learning activity}

The primary objective of teaching-learning is to improve students' knowledge, abilities, and personalities (Xu, 2012). When it comes to experiential events for students, they should be fun and relevant to their everyday lives and careers. So, PETs should undertake experiential learning activities to help students learn actively.

PETs were competent in leading ELT sessions based on the findings. The average score for conducting English teaching-learning activities by PETs was 3.16. In their efforts, it was demonstrated that they conducted teaching-learning activities in accordance with the lesson plan (on average 3.0), guided and helped students during learning activities (average 3.8), informed students about new knowledge and insights (average 3.0), responded to students' learning faults (average 3.4), implemented teachinglearning based on curriculum content and correlated it into daily life (average 2.6). During this period, the researchers considered that some of the indicators, e.g., managing the classroom, should be improved by some PETs. Classroom management includes studying in groups, discussing in front of the class, involving students in language practice, and using ICT as a learning medium (audio or visual). To this end, future EFL teachers are expected to create learning stages such as cooperation, challenge, and regular evaluation. 


\section{The ability to develop learners' potentials}

Potential refers to a person's inherent power, energy, and aptitude, which they own and possess, and which they must tap into if they are to reap the advantages in their everyday lives (Puspitasari et al., 2016; Wiyono, 2006). A teacher can use several approaches to increase student engagement and creativity. These include 1) the selfesteem approach, which focuses on students' personal growth; 2) the creative approach, which encourages students to solve problems creatively by brainstorming, inquiring, and role-playing. Students' intellectual growth will go hand in hand with the development of all other elements of their personality, including their ethics and morals, when the instructor uses a holistic and humanistic approach to learning in order to help them achieve their full potential. To develop students' full potential in developing healthy selfconcepts, teachers can utilize a variety of approaches, such as the following: 1) the multiple-talents method, 2) inquiry-based learning, and 3) the inquiry-based learning approach. To assist pupils and enhance their critical and creative thinking abilities, the instructor employs a pictorial riddle technique, in which they devise strategies for motivating and enticing them to participate in small group conversations. Instructional techniques are introduced by engaging in illogical activities before rational exploration and problem-solving (Rusyan et al., 2020).

In addition, the researchers discovered that PETs did a commendable job of attempting to maximize the potential of their students. The average capacity of PETs to enhance their students' potentials was 3.25. Students' efforts to analyze their progress (average 3.2) and design teaching-learning activities that encourage their interest (average 3.1) were demonstrated by the PETs' efforts to engage the students in learning activities that stimulate their creativity and critical thinking (average 2.9). They also showed that they actively paid attention to the students (average 3.3) and identified their interests, talent, potential, and problems. PETs employ a variety of methods during their first-time teaching, including the self-esteem technique, the creative approach, the value clarification and the moral development approach. Meanwhile, some of them have attempted to employ the inquiry strategy as well as the visual riddle approach to solve the problem. 


\section{The ability to maintain student-teacher communication and interaction}

According to Burleson \& Samter (1990), communication skills may be broken down into two categories based on component analysis: "affective oriented" and "nonaffective oriented" abilities. Cognitively complex people value emotional abilities such as ego support, soothing, self-regulatory behavior, and conflict management more. On the other hand, friendship among people with low cognitive complexity is more dependent on nonaffective-oriented skills such as persuasive, storytelling, referential, and conversational competence.

PETs conducted themselves independently to preserve engagement and communication with students. The average score for PETs in sustaining contact and connection with students was 3.48. There were several observations made, including posing an open question to students in order to ascertain their comprehension and maintain their participation (average 3.9), paying attention to students' questions and, if necessary, providing assistance or clarification (average 3.5), giving clear, accurate, and up-to-date responses to students' inquiries (average 3.2), and presenting such cooperative learning activities for a total of 3.2 (average 3.4). Thus, PETs were fairly adept at establishing some form of communication with pupils, both affective (emotional support and soothing) and non-affective (persuasive, narrative, and conversative). Meanwhile, there are certain communication skills that PETs should work on, specifically referential ability and conflict management. As a result, PETs indirectly increased their ability to engage and communicate with students in an EFL classroom, demonstrating how to connect and communicate with pupils during instructional activities.

\section{The ability to conduct assessment and evaluation}

It is possible to categorize evaluations based on their purposes, including selective evaluation, diagnostic evaluation, placement evaluation, evaluation of measuring achievement, and other types of evaluation based on the specific criteria they are used for (Lasari, 2021; Massler, 2014; Quartapelle, 2012). Sax (1997) asserts that norm- and criterion-referenced interpretation, motivation and guidance of learning are some of the functions of evaluation and assessment. Further, he elaborates that formative and summative evaluation, as well as theory development are other functions of evaluation and assessment. 
The difficulty of evaluating and assessing pupils has prevented PETs from practicing a more in-depth examination of their students' progress. There was an average score of 3.26 for PETs' competence to perform assessments and evaluations. Many PETs thought they were quite good at designing assessments based on basic competence or learning objectives (average 3.0), employing various assessment types and techniques (average 3.0), analyzing assessment results to determine student strength and weaknesses, and providing remedial and enrichment instruction (average 3.5), using student responses as a guide for deriving assessment results (average 3.5) and using the results of the assessment as material for the preparation of following learning designs (average 3.4). PETs frequently utilize the exam as an evaluation tool based on what they can do, what the learning goals suggest, and even what is expected of them, such as pre-test (oral test; open question) and post-test. Therefore, the research discovered (formative test).

\section{CONCLUSION}

This study aimed to evaluate Pre-service English teachers (PETs) based on their pedagogical competence in teaching the English language, pedagogical competence and conceptions about oneself, students, class, teaching-learning activities, topic matter, expectations, and classroom experience concern of this study. To what degree their teaching ideas and experience are valuable assets in the Teaching Internship Program is yet to be determined. The findings of this study conclude that a teacher's abilities and beliefs all impact their students' learning, whether it is through their knowledge of English language material or their ability to organize a class. They also impact how well their students learn due to their understanding of their problems and needs to learn. Furthermore, for the first time, Pre-service English teachers (PETs) completed pedagogical tasks, i.e., from preparation to execution to assessment, while they were student-teachers. Meanwhile, they will continue to be required to improve ICT use in ELT classes.

The researchers believe that this research will be able to be developed and examined in various contexts and methodologies. Several challenges are believed to have a significant impact on the findings, including the length of the study, the sample size, the educational level, classroom climate, student and educational history, educational services and amenities, research tools, and so forth. In the future study, it is probable that 
the involvement of a diverse group of respondents, including pre-service teachers, inservice teachers, students, and the principal, research procedures and instruments, and indepth educational perception would be taken into account other things.

\section{REFERENCES}

Adnyani, D. P. D. P. (2015). Professional development for pre-service teacher: A case study of professional development program for pre-service teacher in state university in central Indonesia. http://www.divaportal.org/smash/record.jsf?pid=diva2\%3A815811\&dswid=-5860

Alghasab, M. (2015). Student-student collaboration in wiki mediated collaborative writing activities: Exploring EFL teachers' roles in the collaborative process (Issue October) [University of York https://doi.org/10.1016/j.jbusres.2006.06.003

Avalos, B. (2011). Teacher professional development in teaching and teacher education over ten years. Teaching and Teacher Education, 27, 10-20. https://www.sciencedirect.com/science/article/pii/S0742051X10001435

Bloor, M., \& Wood, F. (2016). Purposive sampling. Keywords in Qualitative Methods. https://methods.sagepub.com/base/download/BookChapter/keywords-inqualitative-methods/n73.xml

Burleson, B. R., \& Samter, W. (1990). Effects of cognitive complexity on the perceived importance of communication skills in friends. Communication Research. https://doi.org/10.1177/009365090017002002

Cho, S., Lee, H. J., \& Herner-Patnode, L. (2020). Factors influencing preservice teachers' self-efficacy in addressing cultural and linguistic needs of diverse learners. Teacher Educator, 55(4), 411-429. https://doi.org/10.1080/08878730.2020.1805835

Creswell, J. W. (2012). Educational research: Planning, conducting and evaluating quantitative and qualitative research (4th ed.). Pearson Education Inc.

Darling-Hammond, L., Wei, R., \& Johnson, C. M. (2009). Teacher preparation and teacher learning: A changing policy landscape. Handbook of Education Policy Research.

DeLuca, C., Chavez, T., Bellara, A., \& Cao, C. (2013). Pedagogies for preservice assessment education: Supporting teacher candidates' assessment literacy development. Teacher $\quad$ Educator, $48(2), \quad 128-142$. https://doi.org/10.1080/08878730.2012.760024

Denzin, N. K., \& Lincoln, Y. S. (2005). The sage handbook of qualitative research (3rd Ed). Sage Publications.

Doering, A., \& Beach, R. (2002). Preservice English teachers acquiring literacy practices through technology tools. Language Learning and Technology, 6(3), 127-146.

Downing, J. J., \& Dyment, J. E. (2013). Teacher educators' readiness, preparation, and perceptions of preparing preservice teachers in a fully online environment: An exploratory study. Teacher Educator, 48(2), 96-109. https://doi.org/10.1080/08878730.2012.760023

Eggen, P., \& Kauchak, D. (2001). Educational psychology: Windows on classrooms. 8th. Upper Saddle River, NJ: Pearson.

Johnson, R. B., \& Christensen, L. (2019). Educational research: Quantitative, qualitative, and mixed approaches. Sage publications.

Kihlgren, P. (2016). Do we need validity?-A critical appraisal of validity in qualitative 
research. lup.lub.lu.se. https://lup.lub.lu.se/student-papers/record/8886747

Köksal, N., \& Çöğmen, S. (2013). Pre-service teachers as lifelong learners: University facilities for promoting their professional development. Eurasian Journal of Educational Research, 53, 21-40. https://doi.org/10.14689/ejer.2013.53.2

Lasari, Y. L. (2021). Online learning classroom management during the Covid-19 Period at PGMI IAIN Batusangkar. Jurnal Kepemimpinan Dan Pengurusan ..., 6(1). https://doi.org/10.34125/kp.v6i1.520

Lohbeck, A., Hagenauer, G., \& Frenzel, A. C. (2018). Teachers' self-concepts and emotions: Conceptualization and relations. Teaching and Teacher Education, 70, 111-120. https://doi.org/10.1016/j.tate.2017.11.001

Massler, U. (2014). Assessment instruments for primary CLIL: The conceptualisation and evaluation of test tasks. Language Learning Journal, 42(2), 137-150. https://doi.org/10.1080/09571736.2014.891371

Namunga, N. W., \& Otunga, R. N. (2012). Teacher Education as a Driver for Sustainable Development in Kenya. kerd.ku.ac.ke. http://kerd.ku.ac.ke/handle/123456789/656

Oliver, P., \& Jupp, V. (2006). Purposive sampling. eprints.hud.ac.uk. http://eprints.hud.ac.uk/id/eprint/2049/

Patton, M. Q. (2002). Qualitative research and evaluation methods (3rd ed.). Sage Publications.

Puspitasari, A., Anugerahwati, M., \& Rachmajanti, S. (2016). Teachers pedagogical and professional competences in CLIL-based primary schools in Indonesian context. International Conference on Education, 105-115.

Quartapelle, F. (Editor). (2012). Assessment and evaluation in CLIL (I). Aeclil - Eacea.

Radford, D. L. (1998). Transferring theory into practice: A model for professional development for science education reform. Journal of Research in Science Teaching: $\quad$ The $\quad$... $\quad$ https://doi.org/10.1002/(SICI)10982736(199801)35:1\%3C73::AID-TEA5\%3E3.0.CO;2-K

Redmond, P., \& Lock, J. (2019). Secondary pre-service teachers ' perceptions of technological pedagogical content knowledge ( TPACK ): What do they really think ? Australasian Journal of Educational Technology, 35(3), 45-54.

Richards, J. C. (2001). Curriculum development in language teaching. Cambridge University Press. https://doi.org/http://doi.org/10.1111/j.15404781.2007.00543_2.x

Rusyan, A. T., Winarni, W., \& Hermawan, A. (2020). Seri pembaharuan pendidikan membangun kelas aktif dan inspiratif. Deepublish.

Ryegård, Å., Apelgren, K., \& Olsson, T. (2010). A Swedish perspective on pedagogical competence. Uppsala University.

Salajan, F. D., Nyachwaya, J. M., Hoffman, J. G., \& Hill, B. D. (2016). Improving teacher candidates' lesson planning competencies through peer review in a wiki environment. Teacher Educator, 51(3), 185-210. https://doi.org/10.1080/08878730.2016.1153179

Sax, G. (1997). Principles of educational and psychological measurement and evaluation. Wadsworth Publishing Company.

Siwatu, K. O. (2011). Preservice teachers' culturally responsive teaching self-efficacyforming experiences: A mixed methods study. Journal of Educational Research, 104(5), 360-369. https://doi.org/10.1080/00220671.2010.487081

Stake, R. E. (1995). The art of case study research. Sage Publications.

Stein, M. K., Smith, M. S., \& Silver, E. (1999). The development of professional 
developers: Learning to assist teachers in new settings in new ways. Harvard Educational Review. https://meridian.allenpress.com/her/article/69/3/237/31710

Tanang, H., \& Abu, B. (2014). Teacher professionalism and professional development practices in South Sulawesi, Indonesia. Journal of Curriculum and Teaching. https://eric.ed.gov/?id=EJ1157754

Uka, A. (2013). A Review on the spiritual values of the education system in Turkish colleges : A case of albania. Beder Journal of Humanities, 1(1).

Ulla, M. B. (2016). Pre-service teacher training programs in the Philippines: The studentteachers practicum teaching experience. EFL Journal, 1(3). https://doi.org/10.21462/eflj.v1i3.23

Wiyono, S. (2006). Manajemen potensi diri (Rev) (2nd Ed). Grasindo.

$\mathrm{Xu}, \mathrm{L}$. (2012). The role of teachers ${ }^{6}$ beliefs in the language teaching-learning process. Theory and Practice in Language Studies, 2(7), 1397-1402. https://doi.org/10.4304/tpls.2.7.1397-1402

Yin, R. K. (2003). Case study research: Design and methods (3rd ed.). Sage Publications. 